\title{
ПЕРВЫЕ НАХОДКИ SENECELLA SIBERICA VYSHKVARTZEVA 1994 (СОРЕРОDА, САLANOIDA) В БОЛЬШИХ НОРИЛЬСКИХ ОЗЕРАХ (БАССЕЙН РЕКИ ПЯСИНА, ЦЕНТРАЛЬНАЯ СИБИРЬ)
}

\author{
(C) 2018 г. О. П. Дубовская ${ }^{1,2, ~ * ~, ~ Л . ~ А . ~ Г л у щ е н к о ~}{ }^{2, * *}$ \\ ${ }^{1}$ Институт биофизики Федерального исследовательского центра “Красноярский научный центр \\ Сибирского отделения Российской Академии наук”, Красноярск 660036, Россия \\ ${ }^{2}$ Сибирский федеральный университет, Красноярск 660041, Россия \\ *e-mail:dubovskaya@ibp.krasn.ru \\ **e-mail:loraglushchenko@gmail.com \\ Поступила в редакцию 25.01.2018 г.
}

\begin{abstract}
Большие глубокие Норильские озера - Лама, Собачье, Глубокое и Кета - расположены за полярным кругом на северо-западной окраине плато Путорана. Они подвергались в плейстоцене бореальной морской трансгрессии. Реликт этой трансгрессии, Limnocalanus macrurus Sars 1863 (Copepoda Calanoida), доминирует среди ракообразных зоопланктона этих озер в настоящее время. Симпатрический к L. macrurus реликтовый вид, Senecella siberica Vyshkvartzeva 1994, обнаружен нами в пробах зоопланктона из глубоководных участков озер Лама и Собачье в летне-осенний период 2014-2016 гг. Пробы отбирали сетью Джеди, протягивая ее вертикально с глубин 15, 20(25/30) и/или 50 м до поверхности. Все особи Senecella были старшие копеподиты, в основном стадии CIV в озерах Лама и Собачье в августе и CV в оз. Собачье в сентябре, их численность была низкой (25-2000 экз./м²). Копеподиты обитали в центральной глубоководной зоне этих озер, составляя до 7-14\% общей сырой биомассы зоопланктона в слоях 0-20, 0-50 м. Глубинное местообитание, низкая численность и отсутствие копеподитов CV и взрослых особей в летний период могут быть причинами отсутствия Senecella в результатах прежних немногочисленных отборах проб в этих озерах.
\end{abstract}

Ключевые слова: Senecella siberica, морской ледниковый реликт, зоопланктон, Норильские озера, Центральная Сибирь

DOI: $10.1134 /$ S0044513418100057

Во многих глубоких озерах Северной Америки обитает веслоногий рачок Senecella calanoides Juday 1923 (Copepoda, Calanoida). Рачок отмечен в Великих озерах Святого Лаврения, где образует постоянные популяции в Верхнем, Гуроне и Мичигане (Balcer et al., 1984; Barbiero et al., 2001; Bunnell et al., 2015; Burgess et al., 2015), в глубоких озерах центральной и восточной Канады (Carter, 1969; Carter, Goudie, 1986) и севера США (Carter, 1969; Wilson, 1972; Mace, 1979; Torke, 2001). S. calanoides встречается только на территориях, прежде занятых ледниковыми озерами или истоками из них, и поэтому считается ледниковым реликтом (Carter, 1969; Mace, 1979; Carter et al., 1984). Дифференциация S. calanoides датируется плейстоценом, и этот вид рассматривается как реликт плейстоценовой бореальной морской трансгрессии и последующего за ней оледенения (Пирожников, 1958; Dadswell, 1974; цит. по: Burgess et al., 2015). Senecella часто встречается вместе c Limnocalanus macrurus Sars 1863, другим “ледниковым” (“морским ледниковым”, “арктиче- ским") реликтом, или “ледниковым иммигрантом” (Пирожников, 1958; Carter, 1969; Wilson, 1972; Vanderploeg et al., 1998; Torke, 2001). То есть оба вида, L. macrurus и $S$. calanoides, попали в пресные воды из арктических морей в плейстоценовый период.

В Азии, а именно в Сибири, популяции $S$. calanoides были найдены в прибрежных опресненных водах Карского моря и моря Лаптевых (Пирожников, 1958; Khlebovich, Abramova, 2000), в эстуариях Оби, Гыды и Енисея (см. Боруцкий и др., 1991). Вышкварцева (Vyshkvartzeva, 1994) выделила из $S$. calanoides новый вид S. siberica, основываясь на морфологических отличиях особей из залива Неелова моря Лаптевых. Она предположила, что все особи из северной Сибири, ранее относимые к $S$. calanoides, принадлежат $S$. siberica. В настоящее время плотные скопления $S$. siberica наблюдаются в пресной зоне и на южной границе эстуарной фронтальной зоны Обской губы в конце сентября регулярно в различные годы (Dritz et al., 2016). В целом, два сосуществующих 
вида копепод, S. siberica и L. macrurus, доминируют в зоопланктонных сообществах Обского залива (Dritz et al., 2016a), они населяют Енисейский залив (Dritz et al., 2015) и прилегающие прибрежные участки Карского моря (Hirche et al., 2006).

Вышкварцева (Vyshkvartzeva, 1994) также предположила, что S. siberica может населять пресные водоемы северной Сибири (или там она может быть заменена третьей таксономически отличной формой Senecella). В пресных водах северной Сибири Senecella (как S. calanoides) была обнаружена в Западной Сибири, а именно, на Гыданском п-ове: в большом ледниковом озере Ямбуто, устьях рек Гыда и Гыдасе, и близлежащем к последней небольшом безымянном озере (Бурмакин, 1941, цит. по: Vyshkvartzeva, 1994).

Большие пресные Норильские озера бассейна р. Пясина, а именно Лама, Мелкое, Собачье, Глубокое и Кета, лежат на северо-западной окраине плато Путорана в зоне северной тайги (Гордеева, 1964; Заделенов и др., 2017) и подвергались в плейстоценовый период бореальной морской трансгрессии (Вершинин, 1960). Реликт этой трансгрессии, L. macrurus, доминирует в ракообразном зоопланктоне этих озер сейчас (Гордеева, 1964; Dubovskaya et al., 2010). Встречается и другой морской реликт ледникового периода Mysis relicta Lovén 1868 (Вершинин, 1960; О.П. Дубовская, неопубликованные данные). Поэтому вероятность обнаружения в Норильских озерах Senecella представлялась нам большой. Эти озера все еще мало изучены вследствие логистических трудностей, и предыдущие гидробиологические исследования здесь были спорадическими и довольно поверхностными (Заделенов и др., 2017). Три ранее опубликованных списка видов зоопланктона Норильских озер и прилегающих территорий (Гордеева, 1964; Шевелева, 2006; Dubovskaya et al., 2010) не содержат Senecella.

Целью работы был отбор проб зоопланктона в глубоководных частях некоторых Норильских озер и поиск в них особей Senecella, а в случае их обнаружения - определение вида и возрастного состава, частоты встречаемости, численности, биомассы и распределения в озерах.

\section{МАТЕРИАЛЫ И МЕТОДЫ}

В 2014-1016 гг. мы отбирали пробы зоопланктона только на озерах Лама и Собачье (рис. 1), которые являются большими (площадь 318-99 км² соответственно), глубокими (глубина 250-160 м), тектонического происхождения, олиготрофными, с мягкой нейтральной или слабо щелочной водой (рН 6.8-7.7) (Гордеева, 1964; Заделенов и др., 2017). Температура поверхностной воды в озерах в августе и сентябре низкая, в 2014-2016 гг. она была 5.8-12.1 и $6.2-8.4^{\circ} \mathrm{C}$ соответственно. В озерах преобладают арктические пресноводные рыбы семейства лососевые: арктические гольцы комплекса Salvelinus alpinus (Linnaeus 1758); семейства сиговые: сибирская ряпушка (Coregonus sardinella Valenciennes 1848), валек (Prosopium cylindraceum (Pallas et Pennant 1784)), сиг-пыжьян (Coregonus lavaretus pidschian (Gmelin 1788)), муксун (C. muksun (Pallas 1814)), чир (C. nasus (Pallas 1776)), тугун (C. tugun (Pallas 1814)); семейства хариусовые: восточно-сибирский хариус (Thymallus arcticus pallasi Valenciennes 1848); в том числе эндемичные формы с неясным таксономическим статусом, например, голец “пучеглазка” (Павлов и др., 1999).

Створы отбора проб зоопланктона представлены на рис.1, а станции и даты перечислены в табл. 1. На станциях с глубиной более 20 м пробы отбирали сетью Джеди (диаметр входного отверстия 0.25 м $^{2}$, ячея 82 мкм), протягивая ее вертикально с глубины 15, 20(25/30) и/или 50 м до поверхности (табл. 1). В прибрежной литорали пробы отбирали ведром, процеживая 105-120 л воды через сеть с ячеей 82 мкм. Зоопланктон из фиксированных формалином проб определяли и подсчитывали в лаборатории, используя стандартный счетный метод (Методические рекомендации..., 1984), бинокуляр и микроскоп Axioskop 40 (Carl Zeiss) с камерой "MC-3254R/MFG 3ccd color video camera" (AVT-Horn, Aalen, Germany). Сырую массу каждого вида ( $W$, мг) рассчитывали по формуле $W=a L^{b}$, где $L-$ средняя длина тела, мм; $a$ и $b-$ традиционные видовые (групповые) коэффициенты (Методические рекомендации..., 1984). Для Senecella использовали $a$ и $b$, определенные для L. macrurus, так как по данным Бёджес с соавторами (Burgess et al., 2015) эти виды не отличались по средней массе. Ключи Чайки (Czaika, 1982) использовали для определения рода и стадий копеподитов, видовую идентификацию проводили по работам (Vyshkvartzeva, 1994; Markhaseva, 1996). В связи с отсутствием у самок Senecella 5-й пары ног, идентификация рода и пола возможны начиная с 4-й стадии (Czaika, 1982; Balcer et al., 1984; Боруцкий и др., 1991).

\section{РЕЗУЛЬТАТЫ}

Самцы и самки старших копеподитных стадий Senecella были обнаружены в некоторых пробах, взятых в 2014-1016 гг. в озерах Лама и Собачье и ранее обработанных пробах 2003 г. из оз. Лама среди группы “Calanoida копеподиты”. По самцам (Czaika, 1982) копеподиты в начале августа в обоих озерах были 4-й стадии (CIV). А копеподиты 5-й стадии (CV, рис. 2a) доминировали в оз. Собачье в сентябре (по оз. Лама данные за сентябрь отсутствуют, табл. 1). И в это время признак у самок - число щетинок на эндоподите максиллярной ноги $(17=2+3+3+2+3+4$, (Czaika, 1982)) также соответствовал 5-й стадии. Большинство копеподитов имели в теле многочислен- 


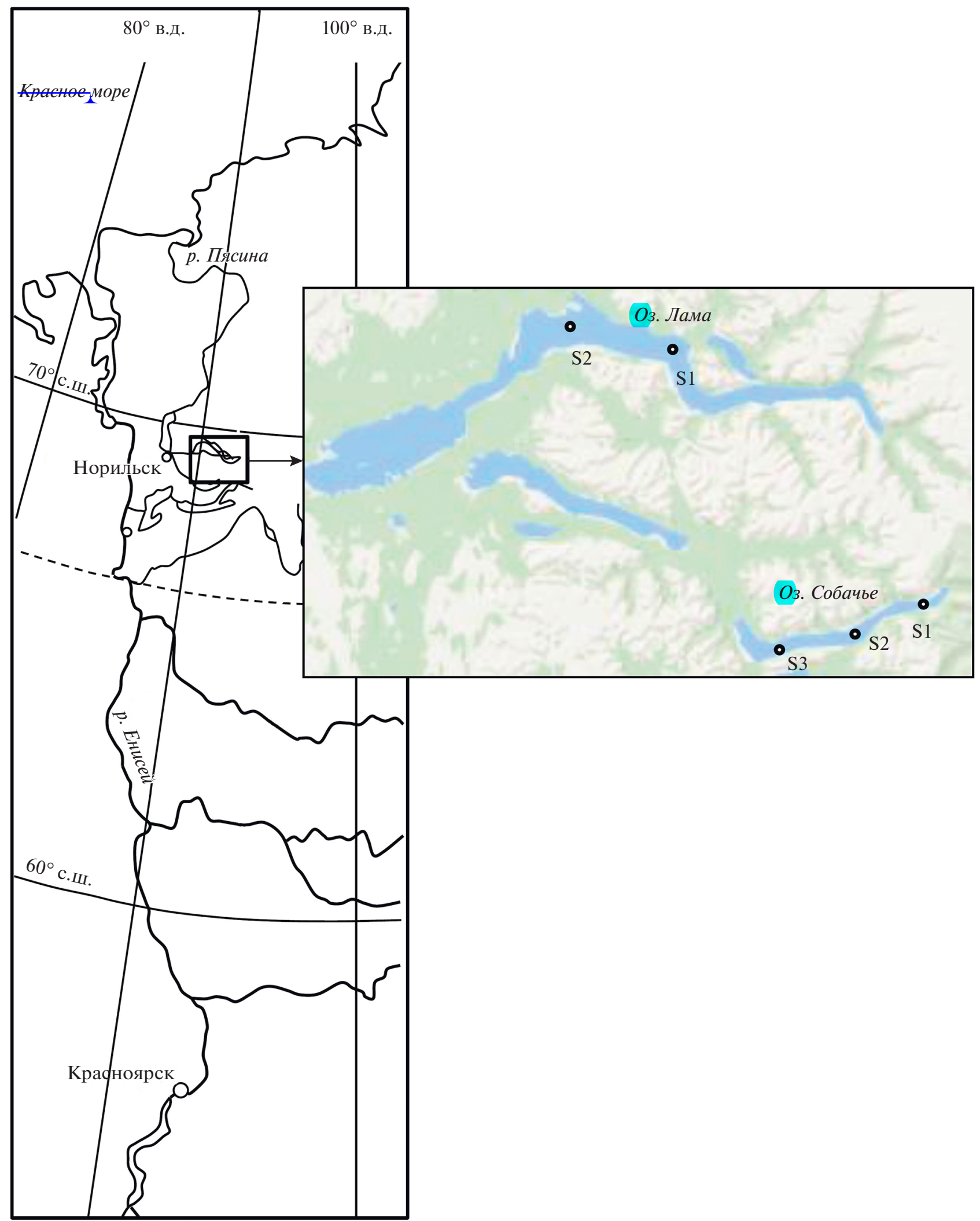

Рис. 1. Карта-схема исследуемых озер со створами отбора проб S1-S3, каждый створ включает одну пелагическую и две литоральные станции. 
Таблица 1. Станции и даты отбора проб зоопланктона на озерах Лама и Собачье

\begin{tabular}{|c|c|c|c|c|c|}
\hline \multirow[b]{2}{*}{ Станции } & \multicolumn{2}{|c|}{ Оз. Лама } & \multicolumn{3}{|c|}{ Оз. Собачье } \\
\hline & 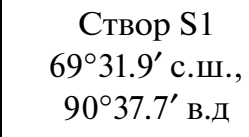 & $\begin{array}{c}\text { Створ S2 } \\
\text { 69³4.2' с.ш., } \\
90^{\circ} 11.0^{\prime} \text { в.д. }\end{array}$ & 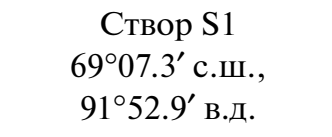 & 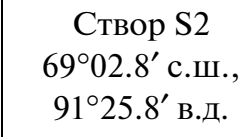 & $\begin{array}{c}\text { Створ S3 } \\
\text { 6901.6' с.ш., } \\
91^{\circ} 05.6^{\prime} \text { в.д. }\end{array}$ \\
\hline $\begin{array}{l}\text { Левый берег } \\
\text { (литораль) }\end{array}$ & 30.07 .03 (л) & - & $\begin{array}{l}30.07 .15(0-15) \\
23.09 .15 \text { (л) } \\
28.09 .16 \text { (л) }\end{array}$ & $\begin{array}{c}- \\
22.09 .15 \text { (л) } \\
-\end{array}$ & $\begin{array}{c}- \\
22.09 .15 \text { (л) } \\
25.09 .16 \text { (л) }\end{array}$ \\
\hline $\begin{array}{l}\text { Середина } \\
\text { (пелагиаль) }\end{array}$ & $30.07 .03(\mathbf{0}-\mathbf{2 0})$ & $\begin{array}{l}6.08 .14(0-2, \\
\mathbf{0}-25)\end{array}$ & $\begin{array}{l}2.08 .14(\mathbf{0}-\mathbf{3 0}) \\
30.07 .15(0-20) \\
23.09 .15(0-30) \\
28.09 .16(\mathbf{0}-\mathbf{5 0}, 0-25)\end{array}$ & $\begin{array}{c}2.08 .14(\mathbf{0}-\mathbf{3 0}) \\
- \\
22.09 .15(0-30) \\
28.09 .16(\mathbf{0}-\mathbf{5 0})\end{array}$ & $\begin{array}{l}2.08 .14(\mathbf{0}-\mathbf{3 0}) \\
- \\
22.09 .15(\mathbf{0}-\mathbf{3 0}) \\
25.09 .16(0-50,0-25)\end{array}$ \\
\hline $\begin{array}{l}\text { Правый берег } \\
\text { (литораль) }\end{array}$ & 30.07 .03 (л) & - & $\begin{array}{l}30.07 .15(0-15) \\
23.09 .15 \text { (л) } \\
28.09 .16 \text { (л) }\end{array}$ & $\begin{array}{c}- \\
22.09 .15 \text { (л) } \\
28.09 .16 \text { (л) }\end{array}$ & $\begin{array}{c}- \\
22.09 .15 \text { (л) } \\
25.09 .16 \text { (л) }\end{array}$ \\
\hline
\end{tabular}

Примечания. В скобках - высота фильтруемого сетью столба воды, м; л - литоральные пробы, отобранные на глубине не более 1.5 м; жирным шрифтом выделены пробы, в которых Senecella присутствовала.

ные капли жира, которые загрязняли предметные и покровные стекла при микроскопировании (рис. 2a).

Что касается видовой принадлежности S. calanoides или $S$. siberica, - то один важный признак, "3 внешних шипа на 3-м членике экзоподита 2-4-й плавательных ног” (Vyshkvartzeva, 1994), позволяет отнести найденных нами особей к виду S. siberica Vyshkvartzeva 1994 (рис. 2б). Поэтому пока мы считаем, что озера Лама и Собачье населены $S$. siberica.

Частота встречаемости S. siberica была максимальной в пелагических пробах из оз. Лама и пелагических пробах из водного столба 50-0 м в оз. Собачье (табл. 2), где особи S. siberica не были найдены в пробах с глубин менее 30 м (табл. 1). Что касается горизонтального распределения вдоль озера, то Senecella найдена на центральных пелагических станциях всех обследованных створов (рис. 1) в обоих озерах (табл. 1 и 2).

Численность Senecella была низкой и изменялась между 25 (50-0 м, оз. Собачье) и 2000 экз $/ \mathrm{м}^{2}$ (20-0 м, оз. Лама) в столбе воды, варьирующем в

Таблица 2. Частота встречаемости (\%) Senecella siberica в зоопланктонных пробах

\begin{tabular}{c|l|c|c}
\hline Биотоп & \multicolumn{1}{|c|}{ Слой } & Оз. Лама & Оз. Собачье \\
\hline Пелагиаль & $0-2 \mathrm{м}$ & $100(n=1)$ & - \\
& $0-20(25 / 30) \mathrm{м}$ & $100(n=2)$ & $44.4(n=9)$ \\
& $0-50 \mathrm{м}$ & - & $66.7(n=3)$ \\
Литораль & $0-15 \mathrm{M}$ & - & $0(n=2)$ \\
& $0-1.5 \mathrm{м}$ & $0(n=2)$ & $0(n=11)$ \\
\hline
\end{tabular}

Примечания. Прочерк - пробы отсутствуют, $n-$ количество проб. высоте от 50 до 20 м. Науплии копепод, преимущественно Cyclops, доминировали по численности в сетном (отобранном сетью, размер ячеи 82 мкм) зоопланктоне пелагиали оз. Лама в августе, составляя более 30-60\% общей численности. А копеподиты Senecella составили только 1.2-1.4\% общей численности сетного зоопланктона. В оз. Собачьем в августе и сентябре коловратки были наиболее обильны, составляя до 91\% численности сетного зоопланктона (здесь и далее данные по пробам, в которых присутствовала Senecella). Доля численности Senecella была ничтожной, $0.002-0.3 \%$.

В общей сырой биомассе сетного зоопланктона, в отличие от численности, Limnocalanus, Senecella и Cyclops составляли значительную часть, поскольку это довольно крупные копеподы, длиной около 2 мм или более. Так, в о3. Лама доля L. macrurus была максимальной, до 88\%, Senecella обеспечивала 7-14\%, и Cyclops - 3-17\% общей сырой био-

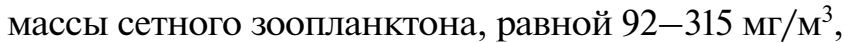
2300-5670 мг/м². Иногда Arctodiaptomus (Rh.) acutilobatus (Sars 1903) составлял до 9\% этой биомассы. В оз. Собачье крупный вид - Asplanchna priodonta Gosse 1850 - иногда превалировал среди коловраток и обеспечивал их доминирование (до $80 \%)$ в общей сырой биомассе сетного зоопланк-

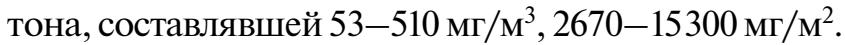
Но чаще в биомассе доминировал L. macrurus с долей 71-79\%, максимальная доля Cyclops lacustris Sars 1863 была 26\%, a Senecella составляла 0.2$7.7 \%$ общей биомассы зоопланктона. Доли Cladocera (Holopedium gibberum Zaddach 1855, Bosmina cf. longispina Leydig 1860) в общей биомассе не превышали $12 \%$.

Некоторые виды сиговых из Собачьего озера тугун и ряпушка - содержали в желудках Limno- 
calanus и Cyclops. Но копеподы не были найдены в желудках сига-пыжьяна (двух форм) и чира (Gladyshev et al., 2017). Senecella пока не найдена в содержимом желудков инспектированных рыб.

\section{ОБСУЖДЕНИЕ}

Судя по многочисленным жировым каплям в теле копеподитов CV из оз. Собачье в сентябре, популяция Senecella в это время была на стадии активного накопления липидов перед последней линькой и превращением в половозрелых особей с последующим размножением. Из этого с большой вероятностью следует, что этот вид в озерах Лама и Собачье размножается зимой, как во многих других озерах Северной Америки, где Senecella ( $S$. calanoides) известна как моноциклический вид с длительным временем развития генерации, выметывающий яйца зимой (Carter, 1969; Mace, 1979; Balcer et al., 1984; Torke, 2001; Dritz et al., 2016а). Картер с соавторами (Carter et al., 1984) полагали облигатным зимнее размножение $S$. calanoides.

Из двух известных видов рода Senecella $S$. calanoides и $S$. siberica - обнаруженных нами копеподитов мы определяем как $S$. siberica, к которому теперь относят солоноватоводные сибирские популяции Senecella, населяющие эстуарии Оби, Гыды и Енисея и прибрежье морей Карского и Лаптевых (Vyshkvartzeva, 1994; Markhaseva, 1996; Hirche et al., 2006; Drits et al., 2015; 2016; 2016а). Наши находки именно $S$. siberica подтверждают предположение Вышкварцевой (Vyshkvartzeva, 1994) о том, что этот вид может населять и пресные водоемы севера Сибири. Однако для точного определения вида необходимы половозрелые самцы, так как по мнению Вышкварцевой (Vyshkvartzeva, 1994) этот вид в пресных озерах может быть заменен третьей таксономически отличной формой Senecella. Чтобы найти половозрелых самцов с высокой вероятностью, необходимо брать зимние пробы, что нами и планируется.

Так как $S$. siberica в обоих озерах была найдена только на пелагических станциях, а в оз. Собачьем отсутствовала в верхних слоях до глубины 25 м, можно предположить, что этот вид обитает только в центральном более глубоком участке пелагиали озер по всей их длине, преимущественно заселяя глубокие слои гиполимниона, как S. calanoides во многих озерах Северной Америки (Carter, 1969; Balcer et al., 1984; Carter, Goudie, 1986; Torke, 2001). S. calanoides способна совершать суточные вертикальные миграции, поднимаясь вечером до верхней границы термоклина или выше, в эпилимнион (Carter, Goudie, 1986). Амплитуду этих миграций, и в целом вертикальное и горизонтальное распределение этого вида (в дневное время) исследователи связывают с прессом рыбпланктофагов, которые выедают рачков. Это выедание обычно происходит днем в верхних осве-

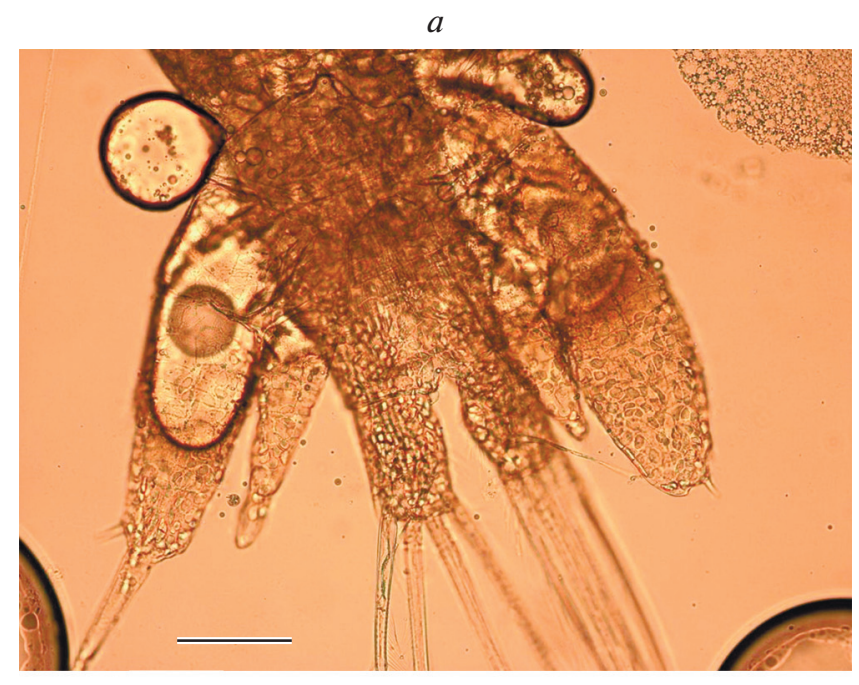

6

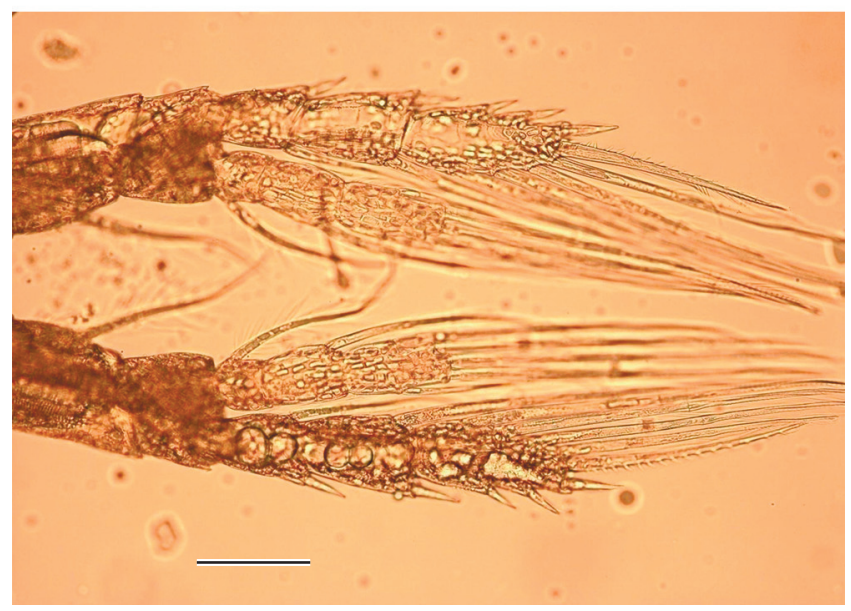

Рис. 2. Оптические фотографии Senecella siberica из оз. Собачье, створ S2, 28.09.2016: $a$ - самец CV, 5-я нога и абдомен ниже, с жировыми каплями; б - 4-я нога самки CV. Масштаб 0.1 мм.

щенных слоях водоема, которые и вынуждены избегать крупные рачки (Carter, Goudie, 1986). Если допустить, что в оз. Лама по сравнению с оз. Собачье пресс планктофагов на популяцию Senecella слабее, то ее вертикальное распределение в первом озере может быть менее стратифицированным, чем во втором, причем рачки могут находиться днем в верхних слоях. Что и показывают наши данные - особи Senecella в оз. Лама встретились в небольшом количестве в слое $0-2$ м, а в Собачьем избегали слои 0-15, 0-20, 0-25 м (табл. 1). Пресс рыб-планктофагов на копепод оз. Лама может быть слабее в связи с большой рекреационной нагрузкой на озеро со стороны жителей Норильска (для которых это озеро наиболее доступно и привлекательно) и ее последствиям в виде перелова некоторых рыб. Еще в 1999 г. Павлов с 
соавторами (1999, с. 106) писали, что “изменились запасы ряда видов, например, возросла численность валька, плотвы, окуня, ерша, гольяна, сократилась численность некоторых гольцов и сиговых". А в пользу высокого пресса рыб-планктофагов в оз. Собачьем свидетельствует тот факт, что среди преобладающих в восточной части озера рыб названа (Романов и др., 2018) ряпушка - типичный планктофаг, и, кроме нее, планктофагом в этом озере является тугун (Gladyshev et al., 2017).

Senecella может населять слои глубже 50-60 м (Carter 1969; Balcer et al., 1984; Torke, 2001), так что мы могли недооценить ее численность, отбирая пробы в столбе воды не глубже 50 м в глубоководных (>60 м) центральных участках озер. Однако низкая численность $S$. calanoides во многих озерах Северной Америки также отмечалась, по крайней мере, по сравнению с численностью L. macrurus (Carter, 1969; Balcer et al., 1984; Torke, 2001). Haпример, S. calanoides, в отличие от L. macrurus, не попала в таблицы доминирующего мезозоопланктона оз. Мичиган в 2007-2008 гг. в работе Вандеплога с соавторами (Vanderploeg et al., 2012), хотя составляла, наряду с L. macrurus, значительную часть рациона некоторых рыб этого озера в 2010 г. (Bunnell et al., 2015).

Как видно из приведенных данных по биомассе сетного зоопланктона, ее основу составляли ракообразные (Crustacea), и среди них доминировали именно копеподы - L. macrurus, C. lacustris и S. siberica с максимальными долями в биомассе соответственно 88, 17 и 14\% в оз. Лама и 79, 26 и $8 \%$ в оз.Собачье. Более выраженное доминирование копепод по сравнению с кладоцерами характерно для северных олиготрофных водоемов и причины этого обсуждаются в некоторых работах (например, Dubovskaya et al., 2010; Novichkova, Azovsky, 2017). Однако среди копепод доли $S$. siberica в биомассе зоопланктона были наименьшие (до 14-8\%) из-за низкой численности (плотности) этого вида. По-видимому, глубинное положение и разреженность (низкая плотность) популяции делают невозможным массовое потребление этого вида сигами-планктофагами в оз. Собачье, в отличие от более массовых в верхних слоях воды копепод L. macrurus и C. lacustris, обнаруженных в желудках ряпушки и тугуна. Мы не знаем, совершают ли особи $S$. siberica в оз. Собачье ночной подъем к поверхности, но даже если местообитания их и планктофагов (включая Mysis relicta) пересекаются, они могут избежать поедания, как $S$. calanoides, которые являются быстрыми пловцами, в отличие от особей L. macrurus (Carter, Goudie, 1986; Wong, Sprules, 1986). Тем не менее полагаем, что при увеличении доли $S$. siberica в численности и биомассе зоопланктона оз. Собачье, она может оказаться в желудках рыбпланктофагов, как это было в оз. Мичиган при увеличении в зоопланктоне доли копепод, включая
S. calanoides, в 2010 г. по сравнению с 1994-95 гг. (Bunnell et al., 2015). Для проверки приведенных здесь предположений требуются дальнейшие исследования.

\section{ЗАКЛЮЧЕНИЕ}

Senecella siberica впервые найдена в Норильских озерах Лама и Собачье. Этот вид не является недавним вселенцем, а представляет собой аборигена, реликта плейстоценовой морской трансгрессии. Популяция S. siberica в озерах Лама и Собачье в августе представлена преимущественно 4-й копеподитной стадией, а в оз. Собачье в сентябре - 5-й копеподитной стадией. S. siberica в этих озерах, по-видимому, является моноциклическим видом, с длительным развитием генерации и зимним размножением. Это глубоководный вид, населяющий центральный более глубокий участок озер по всей их длине. Копеподы Limnocalanus macrurus и Cyclops lacustris доминируют в сырой биомассе сетного зоопланктона в столбе воды $0-20,0-50$ м, в которой $S$. siberica coставляет 7-14\%. Senecella может быть потенциальной пищей для рыб-планктофагов, однако пока не найдена в содержимом желудков сигов из оз. Собачье. Отсутствие Senecella в желудках рыбпланктофагов, как и в списках видов зоопланктона предыдущих экологических обследований Норильских озер, может быть обусловлено тем, что ее популяции имеют глубинное местообитание и низкую численность, а крупные самые старшие копеподиты и половозрелые особи отсутствуют летом - в период проведения большинства гидробиологических работ.

\section{БЛАГОДАРНОСТИ}

Работа поддержана Государственным заданием в рамках программы фундаментальных исследований РФ (тема № 51.1.1) и Государственным заданием министерства Образования и науки РФ для Сибирского федерального университета (6.1404.2017/4.6).

\section{СПИСОК ЛИТЕРАТУРЫ}

Боруикий Е.В., Степанова Л.А., Кос М.С., 1991. Определитель Calanoida пресных вод СССР. СПб.: Наука. 504 с. (Определители по фауне СССР, издаваемые ЗИН АН СССР. Вып. 157).

Вершинин Н.В., 1960. К вопросу о происхождении реликтовой фауны в Норильской группе озер // ДАН CССР. T. 135. № 3. С. 753-765.

Гордеева Л.В., 1964. Зоопланктон Норильских озер // Вопросы гидробиологии водоемов Карелии: уч. записки Карельского государственного педагогического института. Биологические науки. Т. 15. 1963. Петрозаводск: Карельское книжное изд-во. С. 104-116. 
Заделёнов В.А., Дубовская О.П., Бажина Л.В., Глущенко Л.А., Исаева И.Г., и др., 2017. Новые сведения о биоте некоторых озер западной части плато Путорана // Журнал Сибирского федерального университета, Биология. Т. 10. № 1. С. 87-105.

Методические рекомендации по сбору и обработке материалов при гидробиологических исследованиях на пресноводных водоемах. Зоопланктон и его продукция, 1984. Л.: ГосНИОРХ. 34 с.

Павлов Д.С., Савваитова К.А., Груздева М.А., Максимов С.В., Медников Б.М., и др., 1999. Разнообразие рыб Таймыра: систематика, экология, структура видов как основа биоразнообразия в высоких широтах, современное состояние в условиях антропогенного воздействия. М.: Наука. 207 с.

Пирожников П.Л., 1958. Об ареале и экологии копеподы Senecella calanoides Juday // Зоологический журнал. Т. 37. Вып. 4. С. 625-629.

Романов В.И., Поляева К.В., Никулина Ю.С., 2018. Морфологические особенности и эндопаразитофауна некоторых сиговых и хариусовых рыб в восточной части озера Собачьего (плато Путорана) // Журнал Сибирского федерального университета, Биология. Т. 11. (в печати).

Шевелева Н.Г., 2006. Разнообразие фауны планктона водоемов плато Путорана // Изучение и охрана животных сообществ плато Путорана. (Рабочая группа по Гусеобразным Северной Евразии. ГПЗ “Путоранский”.) Романов А.А. (ред.). М. С. 239-251.

Balcer M.D., Korda N.L., Dodson S.L., 1984. Zooplankton of the Great Lakes: A guide to the identification and ecology of the common crustacean species. Madison: The University of Wisconsin Press. $188 \mathrm{p}$.

Barbiero R.P., Little R.E., Tuchman M.L., 2001. Results from the U.S. EPA's Biological open water surveillance program of the Laurentian Great Lakes: III. Crustacean zooplankton // Journal of Great Lakes Research. V. 27. P. 167-184.

Boxshall G.A., Jaume D., 2000. Making waves: The repeated colonization of fresh water by copepod crustaceans // Advances in Ecological Research. V. 31. P. 61-79.

Bunnell D.B., Davis B.M., Chriscinske M.A., Keeler K.M., Mychek-Londer J.G., 2015. Diet shifts by planktivorous and benthivorous fishes in northern Lake Michigan in response to ecosystem changes // Journal of Great Lakes Research. V. 41. Suppl. 3. P. 161-171.

Burgess S., Jackson E.W., Schwarzman L., Gezon N., Lehman J.T., 2015. Improved estimates of calanoid copepod biomass in the St. Lawrence Great Lakes // Journal of Great Lakes Research. V. 41. P. 484-491.

Carter J.C.H., 1969. Life Cycles of Limnocalanus macrurus and Senecella calanoides, and seasonal abundance and vertical distributions of various planktonic copepods, in Parry Sound, Georgian Bay // Journal of the Fisheries Research Board of Canada. V. 262. P. 2543-2560.

Carter J.G.H., Dadswell M.J., Goudie K., 1984. Univoltine and semivoltine life histories in Senecella calanoides (Copepoda: Galanoida) and their relationship to body size // Canadian Journal of Fisheries and Aquatic Sciences. V. 41. P. 1167-1175.
Carter J.C.H., Goudie K.A., 1986. Diel vertical migrations and horizontal distributions of Limnocalanus macrurus and Senecella calanoides (Copepoda, Calanoida) in lakes of southern Ontario in relation to planktivorous fish // Canadian Journal of Fisheries and Aquatic Sciences. V. 43. P. 2508-2514.

Czaika S.C., 1982. Identification of nauplii N1-N6 and copepodids CI-CVI of the Great Lakes calanoids and cyclopoid copepods (Calanoida, Cyclopoida, Copepoda) // Journal of Great Lakes Research. V. 8. P. 439-469.

Drits A.V., Arashkevich E.G., Nikishina A.B., Sergeeva V.M., Solovyev K.A., Flint M.V., 2015. Feeding of dominant zooplankton species and their grazing impact on autotrophic phytoplankton in the Yenisei Estuary in Autumn // Oceanology. V. 55. № 4. P. 573-582.

Drits A.V., Nikishina A.B., Semenova T.N., Sergeeva V.M., Solovyev K.A., Flint M.V., 2016. Spatial distribution and feeding of dominant zooplankton species in the $\mathrm{Ob}$ river estuary // Oceanology. V. 56. № 3. P. 382-394.

Drits A.V., Pasternak A.F., Nikishina A.B., Semenova T.N., Sergeeva V.M., et al., 2016a. The dominant copepods Senecella siberica and Limnocalanus macrurus in the $\mathrm{Ob}$ Estuary: ecology in a high-gradient environment // Polar Biology. V. 39. P. 1527-1538.

Dubovskaya O.P., Kotov A.A., Korovchinsky N.M., Smirnov N.N., Sinev A.Yu., 2010. Zooplankton of lakes in the spurs of the Putorana plateau and adjacent territories (North of Krasnoyarsk Krai) // Contemporary Problems of Ecology. V. 3. № 4. P. 401-434.

Gladyshev M.I., Sushchik N.N., Makhutova O.N., Glushchenko L.A., Rudchenko A.E., et al., 2017. Fatty acid composition and contents of seven commercial fish species of genus Coregonus from Russian subarctic water bodies // Lipids. V. 52. P. 1033-1044.

Hirche H.J. Kosobokova K.N., Gaye-Haake B., Harms I., Meon B., Nöthig E.-M., 2006. Structure and function of contemporary food webs on Arctic shelves: A panarctic comparison the pelagic system of the Kara Sea - Communities and components of carbon flow// Progress in Oceanography. V. 71. P. 288-313.

Khlebovich V.V., Abramova E.N., 2000. Some problems of crustacean taxonomy related to the phenomenon of Horohalinicum // Hydrobiologia. V. 417. P. 109-113.

Mace S.E., 1979. Senecella calanoides Juday (Calanoida, Copepoda), Mesocyclops leuckarti Claus (Cyclopoida, Copepoda), and Daphnia laevis Birge (Cladocera) in inland Wisconsin lakes // Wisconsin Academy of Sciences, Arts and Letters. V. 67. P. 171-173.

Markhaseva E.L., 1996. Calanoid copepods of the family Aetideidae of the World Ocean. St. Petersburg: ZIN RAN. 331 p.

Novichkova A.A., Azovsky A.I., 2017. Factors affecting regional diversity and distribution of freshwater microcrustaceans (Cladocera, Copepoda) at high latitudes// Polar Biology. V. 40. P. 185-198.

Torke B., 2001. The distribution of calanoid copepods in the plankton of Wisconsin Lakes // Hydrobiologia. V. 453/454. P. 351-365. 
Vanderploeg H.A., Cavaletto J.F., Liebig J.R., Gardner W.S., 1998. Limnocalanus macrurus (Copepoda: Calanoida) retains a marine arctic lipid and life cycle strategy in Lake Michigan // Journal of Plankton Research. V. 20. P. 1581-1597.

Vanderploeg H.A., Pothoven S.A., Fahnenstiel G.L., Cavaletto J.F., Liebig J.R., et al., 2012. Seasonal zooplankton dynamics in Lake Michigan: disentangling impacts of resource limitation, ecosystem engineering, and predation during a critical ecosystem transition // Journal of Great Lakes Research. V. 38. P. 336-352.
Vyshkvartzeva N.V., 1994. Senecella siberica n. sp. and the position of the genus Senecella in Calanoida classification // Hydrobiologia. V. 292/293. P. 113-121.

Wilson M.S., 1972. Copepods of marine affinities from mountain lakes of Western North America // Limnology and Oceanography. V. 17. P. 762-763.

Wong C.K., Sprules W.G., 1986. The swimming behavior of the freshwater calanoid copepods Limnocalanus macrurus Sars, Senecella calanoides Juday and Epischura lacustris Forbes // Journal of Plankton Research. V. 8. P. 79-90.

\title{
The First Records of Senecella siberica Vyshkvartzeva 1994 (Copepoda, Calanoida) in Large Norilsk Lakes, Pyasina River Basin, Central Siberia
}

\author{
O. P. Dubovskaya ${ }^{a, b, \#}$ and L. A. Glushchenko ${ }^{b, \# \#}$ \\ ${ }^{a}$ Institute of Biophysics of the Federal Research Center "Krasnoyarsk Science Center", \\ Siberian Branch of the Russian Academy of Sciences, Krasnoyarsk 660036, Russia \\ \#E-mail:dubovskaya@ibp.krasn.ru \\ ${ }^{b}$ Siberian Federal University, Krasnoyarsk 660041, Russia \\ \#\#E-mail: loraglushchenko@gmail.com
}

\begin{abstract}
The large, deep, freshwater Norilsk lakes (Lake Lama, Lake Sobachye, Lake Glubokoe and Lake Keta) are located beyond the Arctic Circle, at the northwestern edge of the Putorana Plateau. They underwent a Pleistocene boreal marine transgression. A relict of that transgression, Limnocalanus macrurus Sars 1863 (Copepoda, Calanoida), presently dominates the crustacean zooplankton of these lakes. Sympatric with the native relict species L. macrurus, Senecella siberica Vyshkvartzeva 1994, was found in our zooplankton samples taken from the deep parts of lakes Lama and Sobachye in the summer-autumn of 2014-2016. Sampling was performed using a Juday net hauled vertically from a depth of 15, 20(25/30) and/or $50 \mathrm{~m}$ to the surface. All Senecella specimens were older copepodites, mainly CIV stage in Lama and Sobachye lakes in August and CV in Sobachye Lake in September; their abundance was low (25-2000 ind. $\mathrm{m}^{-2}$ ). They inhabited the central deeper regions of the lakes, contributing up to $7-14 \%$ to the total wet biomass of net zooplankton in $0-20$ and $0-$ $50 \mathrm{~m}$ strata. Previous sporadic and rather superficial samplings in these lakes missed Senecella due to its deep locations, low abundance levels and the absence of both the oldest copepodites and adults in summer.
\end{abstract}

Keywords: Senecella siberica, marine glacial relict, zooplankton, Norilsk lakes, central Siberia 